\title{
Outbreak of rotavirus gastroenteritis with high mortality, Nicaragua, 2005
}

\author{
Juan José Amador, ${ }^{1}$ Andrea Vicari, ${ }^{2}$ Reina M. Turcios-Ruiz, ${ }^{3}$ \\ Ana Christian Melendez D., ${ }^{1}$ Mark Malek, ${ }^{3}$ Fabiana Michel, ${ }^{2}$ \\ Sylvain Aldighieri, ${ }^{4}$ Tara Kerin, ${ }^{3}$ Joseph S. Bresee, ${ }^{3}$ \\ Roger I. Glass, ${ }^{3}$ and Jon K. Andrus ${ }^{2}$
}

Suggested citation Amador JJ, Vicari A, Turcios-Ruiz RM, Melendez AC, Malek M, Michel F, Aldighieri S, Kerin T, Bresee JS, Glass RI, Andrus JK. Outbreak of rotavirus gastroenteritis with high mortality, Nicaragua, 2005. Rev Panam Salud Publica. 2008;23(4):277-84.

\begin{abstract}
Objectives. We investigated a nationwide outbreak of severe rotavirus gastroenteritis in Nicaragua in children under 5 years old, leading to many consultations, hospitalizations, and deaths. We questioned whether a vaccine might have prevented these illnesses and deaths, sought to identify risk factors for death, and developed a clinical profile of children hospitalized with diarrhea.

Methods. We conducted a case-control study to determine whether children who died had access to routine immunizations, a proxy predicting access to a rotavirus vaccine. We identified risk factors for death among children who died in the outbreak compared with surviving age-matched controls with diarrhea. We collected stools, clinical data, and immunization data on children hospitalized for diarrhea to test for rotavirus, develop the profile, and forecast future access to a rotavirus vaccine.

Results. The outbreak from February to April 2005 caused 47470 consultations and 52 deaths. Approximately $80 \%$ of cases and controls and $60 \%$ of children hospitalized with diarrhea had access to routine immunizations and would likely have had access to a rotavirus vaccine. With a vaccine efficacy of $85 \%$, up to $51 \%$ of severe rotavirus cases and up to $68 \%$ of deaths could have been prevented if a rotavirus vaccine were available as part of routine childhood immunizations. Study of 35 case-control pairs indicated that severe illnesses, malnutrition, and care by traditional healers were risk factors for death. Rotavirus was found in $42 \%$ of samples from hospitalized children and was associated with severe disease and dehydration. Conclusions. The impact of the seasonal outbreaks of rotavirus disease could be diminished with a rotavirus vaccine, improvements in oral rehydration programs, and training of traditional healers in the proper management of children with acute diarrhea.
\end{abstract}

Key words Rotavirus, gastroenteritis, epidemiology, rotavirus vaccines, Nicaragua.

1 Ministerio de Salud, Managua, Nicaragua.

2 Pan American Health Organization, Washington, D.C., United States of America.

3 Centers for Disease Control and Prevention, Atlanta, Georgia, United States of America. Send correspondence and reprint requests to: Reina M.
Turcios-Ruiz, Centers for Disease Control and Prevention, 4770 Buford Highway, MailStop K-23; telephone: 770-488-6219; fax: 770-488-6242; e-mail: RTurciosRuiz@cdc.gov.

4 Pan American Health Organization, Managua, Nicaragua.
In mid-February 2005, staff of the Ministry of Health of Nicaragua identified an unexpected rise in the number of deaths, consultations, and hospitalizations due to diarrhea among 
young children (1). This observation came from routine review of the weekly number of visits and deaths reported to the ministry from its nationwide network of public clinics and hospitals, which provide health care for approximately $60 \%$ of Nicaraguans across its 17 departments $(2,3)$. The outbreak was initially attributed to unknown causes because no bacteria or parasites were readily identified. General recommendations by the ministry to boil water and improve personal hygiene failed to control the outbreak.

Rotavirus was suspected to be the etiologic agent because similar trends in diarrheal illness among children had been observed several weeks earlier in neighboring El Salvador, with rotavirus detected in most fecal samples tested (4). Additional support was provided when a researcher in Leon, Nicaragua, reported detecting rotavirus by immunochromatography (Rota-Strip, Coris BioConcept, Belgium) in many stool specimens collected from children $<2$ years old with acute diarrhea brought to a Leon hospital for medical attention. National recommendations were revised to emphasize proper management of acute diarrhea with rehydration treatment (5).

The Ministry of Health invited the Pan American Health Organization and the Centers for Disease Control and Prevention (CDC) to assist in the investigation of the outbreak aimed at identifying risk factors for death due to diarrheal illness in order to prevent additional deaths, confirming rotavirus as the etiologic agent, and assessing vaccine coverage among those affected in order to predict whether a rotavirus vaccine might have averted deaths and illnesses.

\section{MATERIALS AND METHODS}

To describe the outbreak geographically and look for a seasonal pattern in the past, we reviewed national data from the Ministry of Health on consultations due to diarrhea since 2000 and deaths since 2003. On a weekly basis, each of the public clinics and hospitals organized into 180 local health sys- tems (Sistema Local de Atención Integral de Salud; SILAIS) report the number of consultations and deaths due to diarrhea among children $<5$ years old. Children under the age of 5 years represent $12 \%$ to $13 \%$ of the Nicaraguan population of more than 5 million (6). In general, the location of public clinics and hospitals reflects the distribution of the population in the country, with more health care facilities located in densely populated areas. At ministry headquarters, the data are compiled in an electronic database. The weekly numbers of consultations due to diarrhea among children $<5$ years old were plotted over time to describe the annual trends of diarrheal diseases among children. Geographic differences in mortality were evaluated by calculating case fatality ratios during the outbreak for each of the 17 departments of Nicaragua.

To identify risk factors for death due to diarrhea, we conducted a casecontrol study. Cases were defined as children $<5$ years old whose deaths from diarrhea were reported by public health authorities between January and early March (weeks 1 to 9, 2005). One age-matched ( \pm 2 months of case's age) control with diarrhea was selected for each case from the logbooks of the same health care facilities case patients had initially attended. We hypothesized that risk factors for death were underlying illnesses (including malnutrition), living far from health care facilities (e.g., rural settings), poverty (indicated by having a single mother with little formal education, lacking indoor toilets, and sharing water sources with neighbors), not receiving oral rehydration solutions, and receiving care from a traditional healer. Data on these risk factors, epidemiologic data (age, gender, place of residence), and clinical data were gathered from medical records on cases and controls and supplemented by interviewing the child's primary caregiver. A gastroenteritis severity score, the Ruuska-Vesikari score (7), was constructed based on symptoms recorded in the patient charts at the time of evaluation at a health care facility and illnesses were categorized as moderate or severe if the score totaled $>11$ of a maximum of 20 points. Data were analyzed with SAS version 8 (SAS Institute, Cary, NC). We tested differences in continuous variables such as age and duration of illness for statistical significance with the Wilcoxon rank sum and KruskalWallis tests. For paired analyses of categorical variables, we calculated McNemar odds ratios and 95\% confidence intervals. We considered analyses with resulting $P$ values $<0.05$ reflective of statistically significant differences.

To characterize the role of rotavirus among children with acute gastroenteritis, fecal specimens as well as epidemiologic and clinical data were systematically gathered from children $<5$ years old admitted between March 11 and 17, 2005 (weeks 10 and 11), at any one of four hospitals located in the cities of Managua, Leon, and Estelí. Hospitals were chosen for ease of access, willingness to participate, and representativeness of areas reporting high numbers of cases of diarrhea with high case fatality rates. Data were analyzed in a similar fashion as in the case-control study. Stool samples were tested for rotavirus with an enzyme immunoassay (Premier Rotaclone ${ }^{\circledR}$, Meridian Bioscience Inc., Cincinnati, $\mathrm{OH})$. A sample of rotavirus strains was genotyped at CDC laboratories to determine whether the outbreak was due to a single common strain.

We hypothesized that a rotavirus vaccine might have prevented death or severe illness only if the deceased or ill child had been immunized with the similarly scheduled pentavalent vaccine in a timely manner. This pentavalent vaccine against diphtheria, tetanus, pertussis, hepatitis B, and Haemophilus influenza type $\mathrm{b}$ is administered routinely at 2, 4, and 6 months of age in Nicaragua. To assess the potential impact of a rotavirus vaccine if one had been available through the immunization program, we inquired about the child's receipt and coverage with childhood vaccines as a proxy for whether the child might have received a rotavirus vaccine if one were available. We multiplied this rate of vaccine coverage by the efficacy reported by the manufacturers of each of the two 
FIGURE 1. Temporal trends in consultations for diarrhea among children < 5 years old, Nicaragua, 2000 to 2005

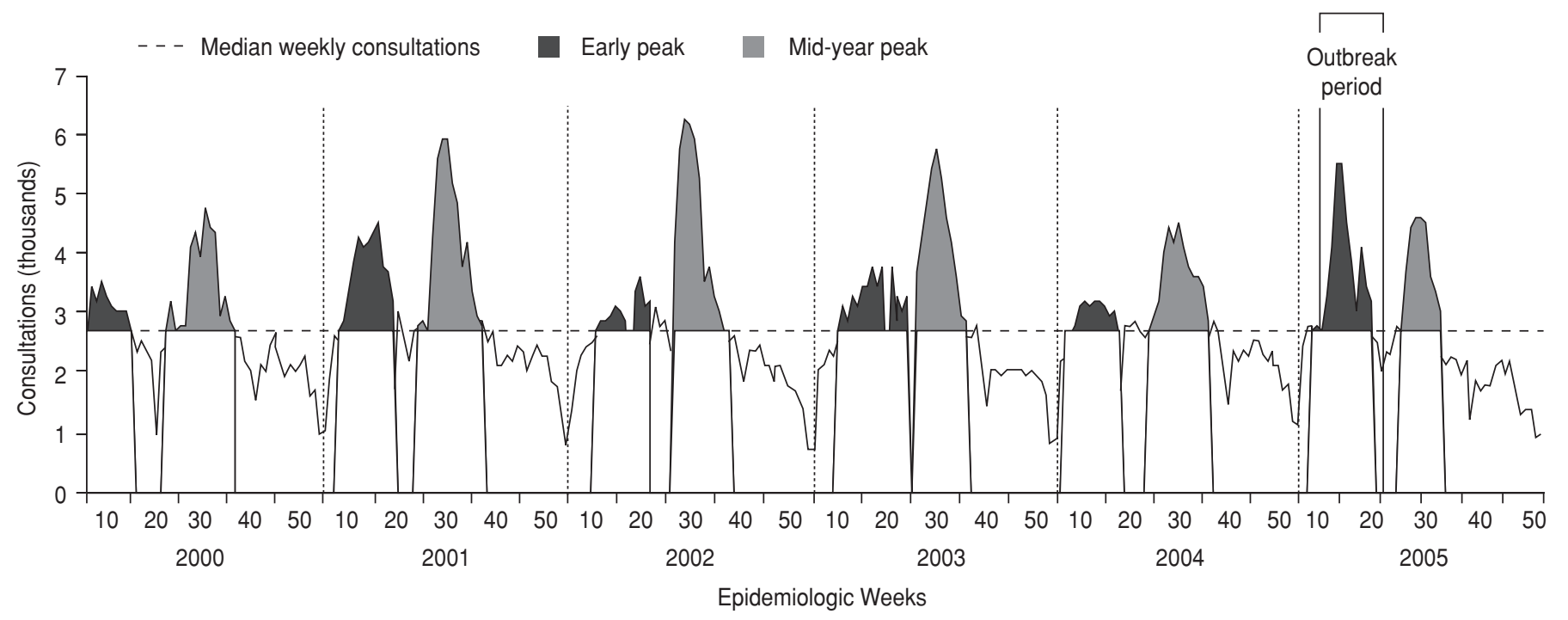

newly developed rotavirus vaccines $(8,9)$, taking into account the severity of illness and circulating strains during the outbreak, to assess properly the future impact of a vaccine had it been in place at the time of this outbreak. In both the case-control study and the study among hospitalized children, we inquired about the child's immunization history: whether the pentavalent vaccine had been administered and at what age.

\section{RESULTS}

In mid-February 2005, staff of the Ministry of Health identified an increase in the weekly number of consultations for acute diarrhea among children $<5$ years of age (Figure 1 ). We reviewed the historic data from 2000 forward and calculated the median number of consultations between 2000 and 2004 to be 2656 per week. Consultations for diarrhea had a seasonal pattern with two clear peaks: one early in the year from January to April and another mid-year from May to August. In the mid-year period (median $=5711$ consultations per week), consultations were nearly double those of the early period (median = 3491 consultations per week). Transitory decreases were observed around the holidays of
FIGURE 2. Temporal trends in deaths due to diarrhea among children $<5$ years old, Nicaragua, 2003 to 2005

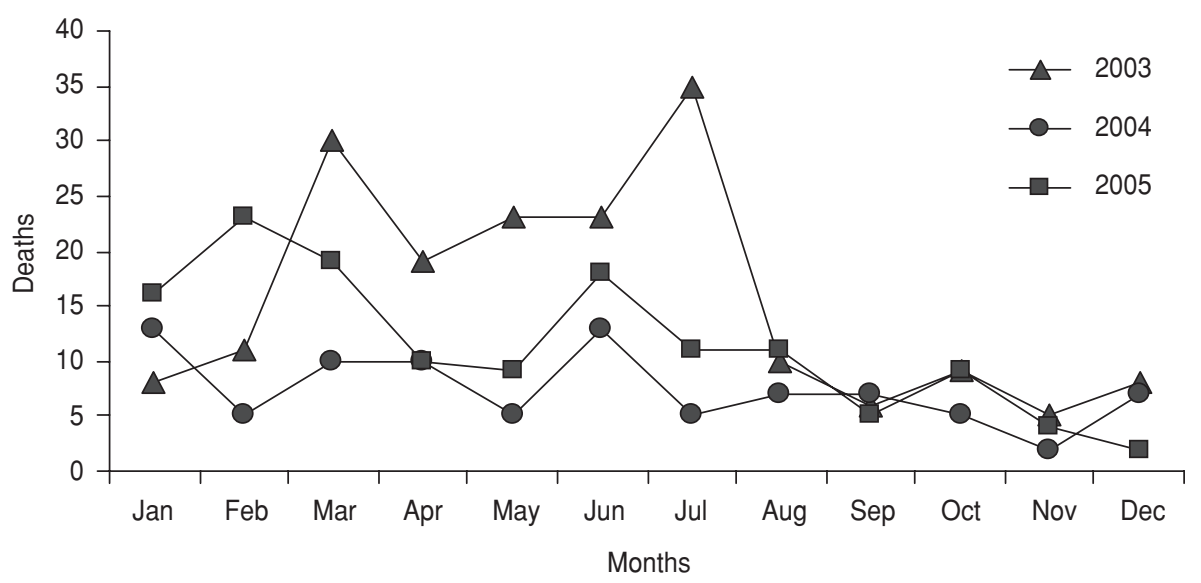

Christmas/New Year (weeks 52 to 1), Holy Week (approximately week 15), and Independence Day (approximately week 38). In 2005, this pattern changed abruptly. Consultations for diarrhea increased sharply in early February (week 6). By March (week 9), the 180 SILAIS throughout the country had reported 5480 consultations per week, exceeding the median of the early peak (about 3500 clinic visits per week) and approaching that of the mid-year peak (about 5700 consultations per week). This exaggerated early peak in 2005 continued until
May (week 18) and accounted for a total of 47470 clinic visits in the 13week period between weeks 6 and 18 .

An increased number of deaths due to diarrhea among children in 2005 accompanied the rise in consultations for acute diarrhea (Figure 2). Analyses of fatal cases of diarrhea since 2003 indicated that, except for a consistent decrease late in the year (September to November), temporal trends in deaths are less predictable than those for consultations. Nonetheless, the 41 deaths reported from January to early March 2005 (weeks 1 to 9) were more than 
FIGURE 3. Case fatality rates of diarrhea by department, Nicaragua, January to March 2005

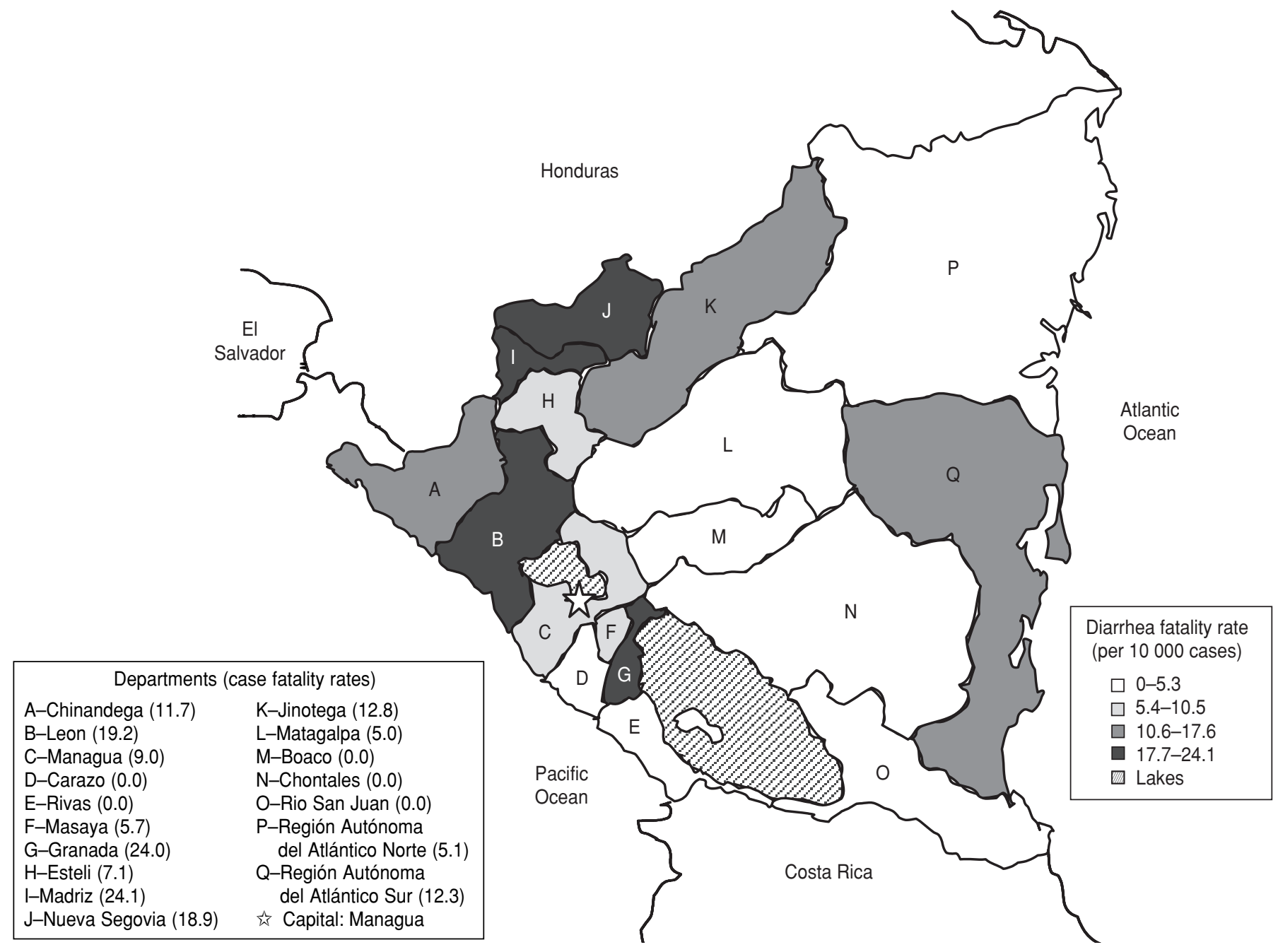

double the number reported for the same period in $2004(n=20)$ and 2003 $(n=19)$. During weeks 6 to 18 (early February to early May 2005), 52 deaths were reported, all among children less than 2 years of age. No stool samples from fatal cases were available for rotavirus testing.

We calculated and compared case fatality rates by department to identify clustering by location (Figure 3). The rates varied widely, from 0 to 24.1 deaths per 10000 cases of diarrhea, and were highest in the departments of Madriz, Granada, Leon, and Nueva Segovia in the more densely populated Pacific and Central regions of Nicaragua. Least affected were the depart- ments of Carazo, Rivas, Boaco, Chontales, and Rio San Juan (case fatality rate of 0 , no fatal cases). The prospective assessment of cases of diarrhea requiring hospitalization was conducted in the capitals of the departments of Managua, Leon, and Estelí.

Characteristics of 35 fatal cases whose medical records or caregivers were available to investigators were compared with those of age-matched and health-care-unit-matched controls (Tables 1 and 2). All 35 fatal cases were under 2 years of age; none was newborn, seven were less than 4 months old, and nine were between 4 and 6 months old. Fatal cases were significantly distinguished from controls by three features: (1) they had more severe illness at the time of evaluation at a health care facility, (2) they were malnourished at the time of illness, and (3) they received care from traditional healers and received laxatives/ purges to "eliminate toxins from the body" before death. Fatal cases tended to live in environments where most were very poor, as indicated by the use of an outdoor latrine instead of an indoor toilet and sharing of water sources with neighbors, although these differences were not significant.

We compared clinical and epidemiologic characteristics of 67 children $<5$ years old admitted for acute diarrhea in any one of four hospitals and 
TABLE 1. Comparison of characteristics expressed as categorical variables of fatal cases of diarrhea versus health-care-unit- and agematched controls occurring among children $<5$ years old during the outbreak period between January and early March 2005 (weeks 1 to 9) in Nicaragua

\begin{tabular}{|c|c|c|c|c|c|c|}
\hline \multirow[b]{2}{*}{ Characteristic } & \multicolumn{4}{|c|}{ Status of case-control pairs $(n=35)$} & \multirow[b]{2}{*}{$\begin{array}{l}\text { McNemar } \\
\text { odds ratio }\end{array}$} & \multirow[b]{2}{*}{$95 \% \mathrm{Cl}^{\mathrm{a}}$} \\
\hline & $\begin{array}{c}\text { Case + } \\
\text { Control + }\end{array}$ & $\begin{array}{c}\text { Case + } \\
\text { Control - }\end{array}$ & $\begin{array}{c}\text { Case - } \\
\text { Control + }\end{array}$ & $\begin{array}{c}\text { Case - } \\
\text { Control- }\end{array}$ & & \\
\hline Principal caregiver, mother & 21 & 8 & 3 & 3 & 2.7 & $0.7-10.1$ \\
\hline Single mother & 1 & 4 & 4 & 26 & 1.0 & $0.2-4.0$ \\
\hline Malnutrition & 6 & 9 & 1 & 11 & 9.0 & $1.1-71.8^{b}$ \\
\hline Severe illness (Vesikari score > 11) & 12 & 15 & 3 & 5 & 5.0 & $1.4-17.3^{b}$ \\
\hline Use of latrine, no indoor plumbing & 24 & 7 & 1 & 3 & 7.0 & $0.9-57.5$ \\
\hline \multicolumn{7}{|l|}{ Prior care for acute gastroenteritis by } \\
\hline Traditional healer & 4 & 16 & 2 & 13 & 8.0 & $1.8-35.1^{b}$ \\
\hline $\mathrm{MOH}$ medical person ${ }^{\mathrm{C}}$ & 2 & 12 & 6 & 15 & 2.0 & $0.7-17.0$ \\
\hline Other medical person & 2 & 7 & 2 & 17 & 1.4 & $0.4-4.4$ \\
\hline \multicolumn{7}{|l|}{ Prior treatment with } \\
\hline Oral rehydration solution & 10 & 12 & 7 & 6 & 1.7 & $0.7-4.4$ \\
\hline
\end{tabular}

a $\mathrm{Cl}$ : confidence interval.

b Statistically significant difference with $P$ value $<0.05$.

${ }^{c} \mathrm{MOH}$, Ministry of Health.

TABLE 2. Comparison of characteristics expressed as continuous variables of fatal cases of diarrhea versus health-care-unit- and age-matched controls occurring among children $<5$ years old during the outbreak period between January and early March 2005 (weeks 1 to 9) in Nicaragua

\begin{tabular}{|c|c|c|c|}
\hline \multirow[b]{2}{*}{ Characteristic } & \multicolumn{2}{|c|}{ Status, median (range) } & \multirow[b]{2}{*}{$P$ value $^{\mathrm{a}}$} \\
\hline & Cases $(n=35)$ & Controls $(n=35)$ & \\
\hline Distance to health facility (minutes) ${ }^{\mathrm{b}}$ & $30(5-420)$ & $20(5-60)$ & 0.12 \\
\hline Age of mother (years) & $21(16-37)$ & $21(15-40)$ & 0.76 \\
\hline Mother's years of schooling & $4(0-11)$ & $4(0-14)$ & 0.81 \\
\hline Duration of illness (hours) ${ }^{c}$ & $29(5-417)$ & $25(0.1-111)$ & 0.06 \\
\hline Length of stay (hours) ${ }^{d}$ & $9(0.2-209)$ & $4.2(0.5-112)$ & 0.85 \\
\hline Pentavalent up to date for age (\%)e & $27(79)$ & $29(83)$ & 0.95 \\
\hline
\end{tabular}

whose stool sample was tested for rotavirus (Table 3$)$. A total of $28(42 \%)$ had rotavirus-positive stools. Characteristics of children with rotavirus gastroenteritis, when compared with those with rotavirus-negative fecal specimens, were significantly less likely to have visible blood in the stool $(0 \%$ versus $18 \%$ ) but more likely to have fever defined as a rectal temperature $>38.5^{\circ} \mathrm{C}(21 \%$ versus $5 \%)$ and to be severely ill (Vesikari scores > 11) $(33 \%$ versus $0 \%$ ) and severely dehydrated (50\% versus $25 \%$ ). Rotavirus-positive and rotavirus-negative children were of similar ages (median 14 versus 11 months) and were equally likely to have received prior treatment for diarrhea.

A total of 27 rotavirus strains were G- and P-typed at CDC. All specimens that gave a P-signal $(n=24)$ were of the $P[8]$ type. Three $G$ strains were identified. G4 was the predominant isolate $(88 \%, n=23)$. G9 was found in three samples (11\%) and G3 was found in two samples $(<1 \%)$, including one sample reflecting a G3/G4 coinfection.

Similar proportions of fatal cases and their age-matched controls with diarrhea and of rotavirus-positive and 
TABLE 3. Comparison of characteristics of rotavirus-positive and rotavirus-negative patients $<5$ years old admitted to any one of four hospitals in Nicaragua between March 11 and 17, 2005

\begin{tabular}{|c|c|c|c|c|}
\hline \multirow[b]{2}{*}{ Characteristic } & \multicolumn{2}{|c|}{ Rotavirus result (\%) } & \multirow[b]{2}{*}{ Odds ratio } & \multirow[b]{2}{*}{$95 \% \mathrm{Cl}^{\mathrm{a}}$} \\
\hline & $\begin{array}{l}\text { Positive } \\
(n=28)\end{array}$ & $\begin{array}{l}\text { Negative } \\
(n=39)\end{array}$ & & \\
\hline Male gender & $13(46)$ & $21(53)$ & 0.7 & $(0.3-2.0)$ \\
\hline Median age in months (range) & $14(1-54)$ & $11(0-42)$ & 1.5 & $(P=0.2)^{b}$ \\
\hline Blood in stool & $0(0)$ & 7 (18) & 0.0 & $(0.0-0.9)^{c}$ \\
\hline Fever (rectal temperature $>38.5^{\circ} \mathrm{C}$ ) & $6(21)$ & $2(5)$ & 5.0 & $(0.8-40.0)^{\mathrm{c}}$ \\
\hline Duration of illness in days (range) & $2(0-14)$ & $1.5(0-8)$ & 0.01 & $(P=0.9)^{b}$ \\
\hline \multicolumn{5}{|l|}{ Illness severity } \\
\hline Severe dehydration ${ }^{d}$ & $14(50)$ & $9(25)$ & 3.3 & $(1.0-11)^{\mathrm{c}}$ \\
\hline Severe illness (Vesikari score $>11)^{\mathrm{e}}$ & $2(33)$ & $0(0)$ & Undefined & \\
\hline Prior treatment ${ }^{\dagger}$ & $6(40)$ & $10(38)$ & 1.1 & $(0.3-3.9)$ \\
\hline Pentavalent up to date for age ${ }^{g}$ & $18(67)$ & $21(58)$ & 1.4 & $(0.4-4.6)$ \\
\hline
\end{tabular}

rotavirus-negative children hospitalized for diarrhea had received pentavalent vaccine doses up to date for their age $(79 \%$ for cases versus $83 \%$ for controls; $67 \%$ for rotavirus-positives versus $58 \%$ for rotavirus-negatives). Considering the estimated vaccine efficacy against severe rotavirus disease associated with the strains identified during the outbreak as $85 \%$ ( $85 \%$ for the GSK vaccine (9) and $88 \%$ to $98 \%$ for the Merck vaccine (8)), 51\% (anticipated coverage $60 \% \times$ vaccine efficacy $85 \%$ ) of severe cases of rotavirus and $68 \%$ (anticipated coverage $80 \% \times$ vaccine efficacy $85 \%$ ) of deaths would have been prevented in Nicaragua during this unusual season of 2005.

\section{DISCUSSION}

We describe a large outbreak of rotavirus gastroenteritis in Nicaragua, which caused great concern because the etiology was initially unknown, and it was associated with high mortality. The early lack of an etiologic diagnosis or understanding of its mode of spread led to recommendations to boil water and improve hygiene, which were ineffective for interrupting the transmission of rotavirus. Upon review of historic data, we confirmed a seasonal pattern in diarrheas and characterized the event as an exaggerated early-year peak of diarrheas among infants that was likely attributable to rotavirus, based on findings from neighboring El Salvador (10) and Honduras (11). The deaths during the outbreak were associated with improper treatment of severe disease by traditional healers (e.g., use of laxatives/ purges and not oral rehydration) and, to a lesser degree, prevailing conditions of poverty indicated by the presence of malnutrition and lack of indoor plumbing. Although severe illness among hospitalized children was associated with rotavirus, it would have been difficult for a physician to distinguish patients with and without rotavirus on clinical grounds alone. While we did not have a confirmed etiologic diagnosis in patients who died in this outbreak, the seasonality, the age of fatal cases, and the strong associations of death with severe illness and of severe illness with rotavirus support considering these deaths as related to rotavirus.

This study confirms that if a rotavirus vaccine had been available, it would have reached those at risk for severe disease and prevented up to half of the cases of severe rotavirus gastroenteritis and more than two- thirds of the diarrheal deaths that occurred in Nicaragua in early 2005 . The 52 deaths due to diarrhea reported by the Ministry of Health between early February and early May were likely fewer than the number of actual deaths due to diarrhea that occurred in the country given that, according to unpublished National Statistics and Census Institute (Instituto Nacional de Estadisticas y Censos) data, only half of all deaths among children $<5$ years old are reported to or by the Ministry of Health (personal communication with S. D. McCracken of CDC, Atlanta, 18 December 2007).

Additionally, the predicted effectiveness of a rotavirus vaccine may be magnified by means of herd immunity whether this vaccine exposes susceptible, unimmunized children to the virus through fecal shedding of vaccine virus by vaccine recipients like live, oral polio vaccines in regions with high levels of viral circulation, or whether the vaccine reduces the number of ill children, potential sources of infection for others like the Haemophilus influenzae conjugate vaccine (12).

Reports of outbreaks of severe winter diarrhea among children due to unknown agents have occurred repeatedly in Central America and the Caribbean (13-17). When the etiology 
is suspected to be viral and diagnostics are less available, general recommendations to improve hygiene, boil water, and wash fruits and vegetables have been ineffective (18), heightening concerns and fears and attracting negative media coverage. Because of the lack of highly effective control measures once an outbreak occurs, attention should focus on identifying strategies to prevent severe illness and deaths. Such strategies include critically evaluating established diarrhea treatment and control programs and considering the introduction of a vaccine against rotavirus. Thus, unlike other outbreak investigations, we not only focused on describing the outbreak and curtailing the spread of the disease but also considered the impact of a vaccine, if one were available.

The outbreak in Nicaragua formed part of a larger phenomenon in the region in the same year. Public health authorities in El Salvador and Costa Rica reported increases in outpatient visits for diarrhea among young children with rotavirus identified as the etiologic agent (4). While large rotavirus outbreaks may be associated with the circulation of uncommon strains as occurred in El Salvador (4), the common G4P[8] strain (19) was identified most frequently in Nicaragua. Thus, the exaggerated earlyyear peak of diarrheas observed in 2005 in Nicaragua may represent expected year-to-year variability observed in other countries monitoring diarrheal activity $(20,21)$ rather than the circulation of a novel strain in the country. Comparisons of the strains implicated in the outbreaks reported in the five Central American countries are under way.

The investigation of this outbreak was limited by the lack of additional bacteriological data and the small number of rotavirus isolates available for characterization. The concurrent circulation of another pathogen could not be confirmed or refuted. However, the timing of the outbreak during the year, the age group of those affected, and the associations between rotavirus detection and severe dehydration and between severe illness and death suggest rotavirus as a leading etiology of acute gastroenteritis leading to hospitalization and death. The lack of additional rotavirus specimens for characterization may have limited the detection of additional circulating strains of the virus, particularly "novel" strains in Nicaragua accounting in part for the occurrence of this exaggerated early-year peak of diarrheas.

This outbreak underscores the importance of implementing surveillance for severe gastroenteritis, particularly that caused by rotavirus, and highlights the need to consider prevention with a vaccine. Rotavirus surveillance, as outlined in the World Health Organization's Generic Protocols for Sentinel Hospital-Based Surveillance (22), would empower authorities to pursue critical activities: (1) identifying the onset and offset of rotavirus season in their country in order to plan and allocate appropriate resources (e.g., assigning additional staff to maintain oral rehydration units open for extended hours and on weekends) and supplies, such as oral and intravenous rehydration solutions, strengthen existing programs/policies to prevent deaths due to diarrhea, and refresh training of health care workers and traditional practitioners on the appropriate evaluation and management of children with diarrhea; (2) fortifying local diagnostic capacity and permitting assessment of strain circulation through the systematic collection and rotavirus testing of fecal specimens; (3) estimating the burden that rotavirus disease represents nationally in order to make a decision about introducing a vaccine; and (4) assessing the effects of the vaccine, if it were adopted.

A rotavirus vaccine would have reached those children at risk for death due to diarrhea and those with disease severe enough to warrant hospitalization and might have prevented numerous consultations, half the hospitalizations, more than two-thirds of the deaths, their resultant high costs, and the increased anxiety associated with this outbreak.

Acknowledgments. We thank Gladys Beatriz Machado, Juan Carlos Mercado L., Angle Balmaseda, Felix Espinoza, Ligia Aragon, Mercedes Vilchez, and Maribel Orozco for their invaluable assistance in conducting this investigation. The findings and conclusions in this report are those of the authors and do not necessarily represent the views of the CDC.

\section{REFERENCES}

1. Ministerio de Salud, Equipo Técnico de Vigilancia Epidemiológica Nacional. Situación epidemiológica de la enfermedad diarreica aguda (EDA) en Nicaragua. Semana 07. Año 2005. Boletín Epidemiológico. 2005. Available from: www.minsa.gob.ni/vigepi/html/ boletin/2005/editorial07.html. Accessed 3 March 2005

2. Pan American Health Organization. Basic country health profiles for the Americas: Nicaragua. Washington, D.C.: PAHO; 2002. Available from: http://www.paho.org/
Spanish/DD/AIS/cp_558.html. Accessed 25 January 2005.

3. Ministerio de Salud, Dirección General de Salud Ambiental y Epidemiología. Manual de vigilancia epidemiológica. Managua, Nicaragua: Ministerio de Salud; 2001.

4. Turcios R, Glass R. Diarrheal illness in Central America January to March 2005. Immunization Newsletter. 2005;XXVII(4):1,6.

5. Ministerio de Salud, Equipo Técnico de Vigilancia Epidemiológica Nacional. Situación epidemiológica de la enfermedad diarreica aguda (EDA) en Nicaragua. Semana 10. Año 2005. Boletín Epidemiológico. 2005. Available from: www.minsa.gov.ni/vigepi/html/ boletin/2005/editorial10.html. Accessed 18 March 2005.

6. Pan American Health Organization, Health Analysis and Statistics Unit. Regional Core Health Data Initiative; technical information system. Washington, D.C.: PAHO; 2007. Available from: www.paho.org/English/ SHA/coredata/tabulator/newsqlTabulator. asp. Accessed 4 January 2008. 
7. Ruuska T, Vesikari T. Rotavirus disease in Finnish children: use of numerical scores for clinical severity of diarrhoeal episodes. Scand J Infect Dis. 1990;22(3):259-67.

8. Vesikari T, Matson DO, Dennehy P, Van Damme P, Santosharn M, Rodriguez Z, et al. Safety and efficacy of a pentavalent human bovine (WC3) reassortant rotavirus vaccine. N Engl J Med. 2006;354(1):23-33.

9. Ruiz-Palacios GM, Perez-Schael I, Velazquez FR, Abate H, Breuer T, Costa Clemens SA, et al. Safety and efficacy of an attenuated vaccine against severe gastroenteritis. N Engl J Med. 2006;354(1):11-22.

10. Guardado JA, Clara WA, Turcios RM, Fuentes RA, Valencia D, Sandoval R, et al. Rotavirus in El Salvador: an outbreak, surveillance and estimates of disease burden, 2000-2002. Pediatr Infect Dis J. 2004;23(10 Suppl):S156-60.

11. Figueroa Sarmiento M, Padilla N, Gutierrez H. Rotavirus en las diarreas infantiles de Honduras. Rev Med Hondur. 1992;1(1):14-20.

12. Bresee JS, Glass RI, Ivanoff B, Gentsch JR. Current status and future priorities for rotavirus vaccine development, evaluation and implementation in developing countries. Vaccine. 1999;17:2207-22.

13. Avalos Rodríguez A. Fallecen 15 niños por diarrea. La Nacion Digital. 6 May 1999. Available from: http://www.nacion.com/ln_ee/ 1999/mayo/06/pais14.html. Accessed 31 January 2006.

14. Matias E. Confirman brote. Según autoridades de salud han muerto cuatro niños. Prensa Libre. 24 January 2006. Available from: http://www.prensalibre.com/pl/2006/ener o/24/132926.html. Accessed 31 January 2006.

15. Ferrufino M. Médicos piden higiene para evitar diarreas. El Diario de Hoy. 4 January 2001. Available from: http://www.elsalvador. com/noticias/EDICIONESANTERIORES/ 2001/ENERO/enero4/NACIONAL/nacio10. html. Accessed 15 June 2004.

16. Anonymous. Practise good hygiene to reduce gastroenteritis, urges ministry. The Jamaica Observer. Internet Edition. 8 February 2002. Available from: http://www.jamaicaobserver. com/news / html/20020207t210000-0500_ 20951_obs_practise_good_hygiene_to_ reduce_gastroenteritis__urges_ministry.asp. Accessed 31 January 2006.

17. Fischer TK, Ashley D, Kerin T, Reynolds-Hedmann E, Gentsch J, Widdowson M-A, et al. Rotavirus antigenemia in patients with acute gastroenteritis. J Infect Dis. 2005;192(5):913-9.

18. LeBaron CW, Furutan NP, Lew JF, Allen JR, Gouvea V, Moe C, et al. Viral agents of gastroenteritis. Public health importance and outbreak management. MMWR Recomm Rep. 1990;39(RR-5):1-24.
19. Castello AA, Arvay ML, Glass RI, Gentsch J. Rotavirus strain surveillance in Latin America: a review of the last nine years. Pediatr Infect Dis J. 2004;23(10 Suppl):S168-72.

20. Turcios RM, Curns AT, Holman RC, PandyaSmith I, LaMonte A, Bresee JS, et al. Temporal and geographic trends of rotavirus activity in the United States, 1997-2004. Pediatr Infect Dis J. 2006;25(5):451-4.

21. Solorzano Giron JO, Molina IB, Turcios-Ruiz RM, Quiroz Mejia CE, Amendola LM, de Oliveira LH, et al. Burden of diarrhea among children in Honduras, 2000-2004: estimates of the role of rotavirus. Rev Panam Salud Publica. 2006;20(6):377-84.

22. World Health Organization. Generic protocols for (i) hospital-based surveillance to estimate the burden of rotavirus gastroenteritis in children and (ii) a community-based survey on utilization of health care services for gastroenteritis in children. Geneva: WHO; 2002. Available from: http://www.who.int/vaccine_research/ diseases/rotavirus/documents/en/. Accessed 25 January 2005.

Manuscript received on 3 January 2007. Revised version accepted for publication on 22 January 2008.
RESUMEN

\section{Brote de gastroenteritis por rotavirus con alta mortalidad, Nicaragua, 2005}

Palabras clave
Objetivos. Se investigó un brote nacional de gastroenteritis grave por rotavirus en niños menores de 5 años de edad que provocó numerosas consultas, hospitalizaciones y muertes en Nicaragua. Se analizó si la vacunación habría evitado estos casos de enfermedad y fallecimiento, se buscaron factores de riesgo de muerte y se elaboró un perfil clínico de los niños hospitalizados con diarrea.

Métodos. Se realizó un estudio de casos y controles para determinar si los niños que murieron tuvieron acceso a programas de vacunación, como medida indirecta del acceso a la vacuna contra rotavirus. Se identificaron los factores de riesgo de muerte en los niños que fallecieron durante el brote en comparación con los controles con diarrea sobrevivientes, emparejados según la edad. Se tomaron muestras de heces fecales, datos clínicos y de vacunación de los niños hospitalizados con diarrea para realizar el diagnóstico de rotavirus, elaborar el perfil clínico y pronosticar el acceso futuro a una vacuna contra rotavirus.

Resultados. El brote ocurrido entre febrero y abril de 2005 ocasionó 47470 consultas y 52 muertes. Aproximadamente $80 \%$ de los casos y controles y $60 \%$ de los niños hospitalizados con diarrea tuvieron acceso a la vacunación programada y posiblemente tuvieron acceso a una vacuna contra rotavirus. Si en los programas de vacunación se hubiera dispuesto de una vacuna de $85 \%$ de eficacia, se hubieran prevenido hasta $51 \%$ de los casos graves de rotavirus y hasta $68 \%$ de las muertes. El estudio de 35 pares de casos y controles demostró que la enfermedad grave, la desnutrición y la atención por curanderos tradicionales fueron los factores de riesgo de muerte. Se encontró rotavirus en $42 \%$ de las muestras de niños hospitalizados, asociado con la enfermedad grave y la deshidratación.

Conclusiones. El efecto de los brotes estacionales de la enfermedad por rotavirus podría reducirse mediante la vacunación contra rotavirus, el perfeccionamiento de los programas de rehidratación oral y el entrenamiento de los curanderos tradicionales en el tratamiento correcto de los niños con diarrea aguda.

Rotavirus, gastroenteritis, epidemiología, vacunas contra rotavirus, Nicaragua. 